\title{
Design and Evaluation of Chronotherapeutic Drug Delivery System of Montelukast Sodium
}

\author{
M. S. Neeharika*, Jeevana Jyothi B \\ Department of Pharmaceutics, Institute of Pharmaceutical Technology, \\ Sri Padmavati Mahila Visvavidyalayam (Women's University), Tirupati, Andhra Pradesh, INDIA. \\ *Corresponding author's E-mail: satyaneeharika@gmail.com
}

Received: 14-01-2021; Revised: 26-02-2021; Accepted: 04-03-2021; Published on: 20-03-2021 ABSTRACT

The objective of the present study was to formulate and evaluate an oral, time-controlled drug delivery system of Montelukast sodium, based on chrono pharmaceutical approach by press coating technology using natural polymers for the treatment of nocturnal asthma. Press coated tablets (PCT1-PCT12) containing Montelukast sodium in the core tablet (CT3) were prepared by compression coating of the core tablet with an outer barrier layer with different compositions of a hydrophobic polymer, Dammar gum and hydrophilic polymers, Xanthan gum, Karaya gum and Locust bean gum. Fourier transform infra-red (FTIR) spectrometry, differential scanning calorimetry (DSC), were applied to investigate the drug-excipient compatibility of the formulation and the studies revealed no chemical interactions between drug and polymers used. The optimized formulation PCT8 yielded a desired lag time of 6 hours followed by burst release of the drug, which is consistent with the demands of chronotherapeutic drug delivery. Stability studies were performed for 3 months at $40 \pm 2 \circ \mathrm{C} / 75 \pm 5 \% \mathrm{RH}$ as per ICH guidelines for optimized formulation and it was found to be stable.

Keywords: Time controlled drug delivery, Chronotherapeutics, Montelukast sodium, Press coated tablets, Lag time.

QUICK RESPONSE CODE $\rightarrow$

DOI:

10.47583/ijpsrr.2021.v67i01.010

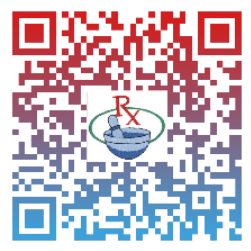

DOI link: $\underline{\text { http://dx.doi.org/10.47583/ijpsrr.2021.v67i01.010 }}$

\section{INTRODUCTION}

ral drug delivery has been known for decades as the most widely utilized route of administration among all the routes that have been explored for the systemic delivery of different dosage forms ${ }^{1}$. To achieve and maintain the drug concentration in the body within the therapeutic range required for a medication, it is often necessary to take this type of drug delivery system several times a day ${ }^{2}$. Chronotherapeutics refers to a treatment method in which in-vivo drug availability is timed in relation to our body's circadian rhythms to produce maximum health benefits. It is becoming increasingly evident that some medications may work better if their administration is coordinated with day night patterns and biological rhythms. For example, researchers have reported that asthma is worst in the early morning hours between 4 a.m. to 6 a.m. In such circumstances, chrono therapeutics plays a prominent role, where the intention is that the formulation is administered in the evening, which provides treatment for disease in which symptoms are experienced in the early morning hours. The principal advantage of chronotherapeutic pharmaceuticals is to provide optimum plasma levels of drug, resulting in maximum health benefits and minimize the undesired ones. As a consequence, there is reduction of dose requirement and this is likely to improve the patient compliance ${ }^{3}$.

Among various timed-release formulations available, compression-coated tablets are the simplest to manufacture. Oral compression coated tablets (CCTs) compose of an inner core that contains an active pharmaceutical ingredient and additives surrounded by an outer layer that dissolves or disintegrates slowly to produce the pre-determined lag time. The advantage of this production technique is that it is simple, inexpensive and it is not hazardous to the environment since it does not require the use of high amounts of organic solvents. CCTs have the unique characteristic that a drug is released from the formulation after a predetermined lag time. A time-release formulation could allow drug release and a greater plasma drug concentration at the point in the circadian cycle when clinical signs develop or increase ${ }^{4}$. CCT can also be used to avoid pharmacokinetic drug-drug interactions between concomitantly administered medications, creating a time interval between their releases into the gastrointestinal tract ${ }^{5}$.

Asthma is a chronic inflammatory disease of the airways, characterized by hyper responsiveness to a variety of stimuli. The role of circadian rhythms in the pathogenesis and treatment of asthma indicates that airway resistance increases progressively at night in asthmatic patients. The worsening of asthma at night, commonly referred to as nocturnal asthma is a variable exacerbation of the underlying asthma condition associated with increase in symptoms, need for medication, airway responsiveness, and/or worsening of lung function. Approximately twothirds of asthmatics suffer from night time symptoms. 
Hence, a chronotherapeutic drug delivery system (ChrDDS) administered at bedtime but releasing drug during morning hours would be ideal in this case ${ }^{6}$.

The objective of the present study was to formulate and evaluate an oral, time controlled drug delivery system of Montelukast sodium (a selective and orally active leukotriene receptor antagonist that inhibits the cysteinyl leukotriene $\mathrm{CysLT}_{1}$ receptor which is chemically designated as $\quad[\mathrm{R}-(E)]-1-[[[1-[3-[2-(7-c h l o r o-2$ quinolinyl) ethenyl]phenyl]-3-[2-(1-hydroxy-1-

methylethyl)phenyl]propyl]thio]methyl]cyclopropaneacet ic acid, monosodium salt) ${ }^{7}$ based on chronopharmaceutical approach by press (compression) coating technology using natural polymers for the treatment of nocturnal asthma.

\section{MATERIALS AND METHODS}

\section{Materials}

Montelukast sodium (obtained as a gift sample from MSN laboratories Pvt Ltd., Hyderabad), avicel PH 101, Anhydrous lactose (purchased from Spectrum Pharma Labs, Hyd), sodium starch glycolate, crosspovidone, talc (purchased from S.D.Fine chemicals, Mumbai), magnesium stearate (from Central drug house (p) Ltd, Bombay), sodium lauryl sulphate (from Rankem Laboratories,
Hyderabad), karaya gum, xanthan gum, locust bean gum and dammar gum (from N.R.Chem., Mumbai)

\section{Methods}

Chronotherapeutic drug delivery system of Montelukast sodium was made in the form of press coated tablets. This was carried out in two stages:

\section{Preparation of Core Tablets by Direct Compression}

The inner core/immediate release tablets containing Montelukast sodium were prepared by direct compression method using super disintegrants like Sodium starch glycolate and cross povidone in various proportions as mentioned in the Table no: 1 . As per formulation variables shown in table below, the powder mixtures of Montelukast sodium, microcrystalline cellulose (Avicel PH101), Sodium starch glycolate, crospovidone and anhydrous lactose were dry blended for $15 \mathrm{~min}$ and further blended for $5 \mathrm{~min}$ following the addition of talc and magnesium stearate. The prepared blends were then evaluated for flow properties like angle of repose, bulk density, tapped density, Carr's index and Hausner's ratio and finally compressed using single punch $\mathrm{CADMACH}$ machine to obtain tablets of $6.0 \mathrm{~mm}$ diameter and weighing $100 \mathrm{mg}$ each. The tablets were packed in aluminum foil, wrapped with brown paper $^{8,9}$.

Table 1: Preparation of Core Tablets by Direct Compression

\begin{tabular}{|c|c|c|c|c|c|c|c|c|c|}
\hline S.NO & INGREDIENTS & CT1 & CT2 & CT3 & CT4 & CT5 & CT6 & CT7 & CT8 \\
\hline 1. & API & 10 & 10 & 10 & 10 & 10 & 10 & 10 & 10 \\
\hline 2. & Anhydrous lactose & 81 & 79 & 77 & - & - & - & 48 & 48 \\
\hline 3. & Avicel PH 101 & - & - & - & 81 & 79 & 77 & 30 & 30 \\
\hline 4. & Crospovidone & - & - & - & 2 & 4 & 6 & 5 & - \\
\hline 5. & Sodium starch glycolate & 2 & 4 & 6 & - & - & - & - & 5 \\
\hline 6. & Talc & 2 & 2 & 2 & 2 & 2 & 2 & 2 & 2 \\
\hline 7. & Magnesium stearate & 5 & 5 & 5 & 5 & 5 & 5 & 5 & 5 \\
\hline 8. & Erythrosin red & qs & qs & qs & qs & qs & qs & qs & qs \\
\hline & Total (mg) & 100 & 100 & 100 & 100 & 100 & 100 & 100 & 100 \\
\hline
\end{tabular}

\section{Optimization/ Selection of Prepared Core Tablets ${ }^{8,9}$}

All the prepared core tablets were optimized by average weight, hardness, friability, thickness, drug content, disintegration time, wetting time and in vitro dissolution for further conversion of selected core tablet in the form of press-coated tablets of Montelukast sodium.

\section{Average weight}

Average weight was carried out for 20 tablets selected at random from the batch containing 100 tablets. The results are given in Table no: 4.

\section{Hardness}

Hardness was determined by Monsanto hardness tester.

\section{Friability}

The friability of 20 tablets was determined by Roche friabilator at $25 \mathrm{rpm}$ for $4 \mathrm{~min}$.

\section{Thickness}

Thickness was measured by vernier calipers.

\section{Drug content}

Drug content was determined by weighing and grinding 10 randomly selected tablets and dissolving powder equivalent to $10 \mathrm{mg}$ of the drug in $100 \mathrm{~mL}$ of distilled water with $0.5 \%$ SLS. The solution was then sonicated for $5 \mathrm{~min}$ and then filtered through $0.45 \mu$ membrane filter. The absorbance of this solution was determined at $342 \mathrm{~nm}$ and drug content was calculated. 


\section{Disintegration time}

The in vitro disintegration studies were carried out using a digital tablet disintegration test apparatus. One tablet was placed in each of the 6 tubes of the basket assembly and then disk was added to each tube. This assembly was then suspended in a 1-litre beaker containing water with its temperature being maintained at $37 \pm 2^{\circ} \mathrm{C}$. The basket was then moved up and down through a distance of 5 to $6 \mathrm{~cm}$, at the frequency of 28 to 32 cycles per minute. The time required for the complete disintegration of the tablet was recorded. It is expressed in seconds.

\section{Wetting time}

A tissue paper folded twice was placed in a petridish. $10 \mathrm{ml}$ of water is added to the petridish. A tablet was carefully placed on the surface of the tissue paper. The time required for water to reach upper surface of the tablet was noted as wetting time.

\section{In vitro dissolution rate studies}

In vitro release rate studies of the core tablets were performed using USP type II apparatus (paddle type) by using $900 \mathrm{ml}$ of distilled water with $0.5 \%$ SLS as the dissolution medium at a speed of 50rpm and a temperature of $37 \pm 0.5^{\circ} \mathrm{C} .5 \mathrm{ml}$ samples were withdrawn through a filter of $0.45 \mu \mathrm{m}$ at different time intervals, suitably diluted and assayed for Montelukast sodium by measuring absorbance at $342 \mathrm{~nm}$. The results are given in Table 5.

\section{Preparation of Press-Coated Tablets of Montelukast Sodium}

The press coated tablets of Montelukast sodium (PCT1PCT12) were prepared by compression coating of the optimised core tablet formulation (CT3) with outer barrier layers of $300 \mathrm{mg}$ each having different compositions of polymers like xanthan gum, karaya gum, locust bean gum and dammar gum, the formulae of which are mentioned in Table no: 2.

Prior to compression, the prepared polymer blends were evaluated for flow properties like angle of repose, bulk density, tapped density, Carr's index and Hausner's ratio. The core tablets were press-coated with $300 \mathrm{mg}$ of prepared barrier blend as per the mentioned formulae from PCT1 to PCT12. 150mg of barrier layer material was weighed and transferred into a $10 \mathrm{~mm}$ die and then the core tablet was placed manually at the center. The remaining $150 \mathrm{mg}$ of the barrier layer material was added into the die and compressed ${ }^{9,10}$.

Table 2: Preparation of Press Coated Tablets

\begin{tabular}{|c|c|c|c|c|c|c|c|c|c|c|c|c|c|}
\hline S. No. & INGREDIENT & РCT1 & РCT2 & РСТ3 & РСT4 & PCT5 & РСТ6 & РСT7 & РСт8 & РСТ9 & $\begin{array}{c}\text { PCT } \\
10\end{array}$ & $\begin{array}{c}\text { PCT } \\
11\end{array}$ & $\begin{array}{c}\text { PCT } \\
12\end{array}$ \\
\hline 1 & Core tablet & 100 & 100 & 100 & 100 & 100 & 100 & 100 & 100 & 100 & 100 & 100 & 100 \\
\hline 2 & Xanthan gum & 150 & 150 & - & - & 100 & 100 & - & - & 200 & 200 & - & - \\
\hline 3 & Karaya gum & - & - & 150 & 150 & - & - & 100 & 100 & - & - & 200 & 200 \\
\hline 4 & Dammar gum & 150 & - & 150 & - & 200 & - & 200 & - & 100 & - & 100 & - \\
\hline 5 & Locust bean gum & - & 150 & - & 150 & - & 200 & - & 200 & - & 100 & - & 100 \\
\hline
\end{tabular}

\section{Evaluation of Press-Coated Tablets ${ }^{11}$}

All the prepared press coated tablets were evaluated for average weight, hardness, friability, thickness, swelling index and in vitro dissolution.

\section{\% Swelling Index}

The tablets were weighed and placed in a petridish containing $10 \mathrm{ml}$ of dissolution medium. At specified time intervals the tablets were removed, lightly blotted with tissue paper to remove excess liquid and then weighed. The swelling index was calculated using the formula,

$$
\text { Swelling index }(\%)=\left[\mathrm{W}_{\mathrm{s}}-\mathrm{W}_{\mathrm{d}} / \mathrm{W}_{\mathrm{d}}\right] * 100
$$

Where, $W_{s}=$ weight of swollen tablet at time' $t^{\prime}$

$$
W_{d}=\text { weight of dry tablet }
$$

\section{In vitro dissolution rate studies}

In vitro release rate studies of the press coated tablets were performed using USP type II apparatus (paddle type) by using $900 \mathrm{ml}$ of distilled water with $0.5 \% \mathrm{SLS}$ as the dissolution medium at a speed of 50rpm and a temperature of $37 \pm 0.5^{\circ} \mathrm{C} .5 \mathrm{ml}$ samples were withdrawn through a filter of $0.45 \mu \mathrm{m}$ for every hour up to 10 hours and the lag time was observed for every batch of tablets. The withdrawn samples were analysed spectroscopically by measuring the absorbance at $342 \mathrm{~nm}$.

\section{Drug - Excipient Compatibility Studies}

Drug-excipient compatibility was studied by analyzing the samples prepared by mixing the excipients with the drug separately in different ratios and the final press coated tablet formulation using FT-IR and DSC studies.

\section{(a) Fourier Transform Infrared Spectroscopy (FTIR)}

FTIR spectra of the pure drug and optimized formulation were recorded in the region of 4000 to $400 \mathrm{~cm}^{-1}$ on an FTIR spectrophotometer (Model ALPHA T Bruker, Germany) with a resolution of $4 \mathrm{~cm}^{-1}$ using Potassium bromide discs prepared from powdered samples.

\section{(b) Differential Scanning Calorimetry (DSC)}

Thermograms of pure Montelukast sodium and optimized formulation were obtained by using a differential scanning 
calorimeter (DSC Q20 V24.4 Build 116, Japan) by heating in sealed aluminum pans under nitrogen flow $(40 \mathrm{~mL} / \mathrm{min})$ and scanning at a heating rate of $10^{\circ} \mathrm{C} / \mathrm{min}$ over a temperature range of $25^{\circ} \mathrm{C}$ to $300^{\circ} \mathrm{C}$.

\section{RESULTS AND DISCUSSION}

\section{Evaluation of Core Tablets}

\section{Evaluation of pre-compression parameters}

Powder blends used for preparing immediate release core tablets (CT's) were evaluated for angle of repose, bulk density, tapped density, Hausner's ratio, Carr's index and the results are shown in Table no: 3 . The values for angle of repose, Hausner's ratio, and compressibility index were found to be in good correlation, indicating that all the formulations possess passable flow property and compressibility.

Table 3: Pre-Compression Parameters

\begin{tabular}{|c|c|c|c|c|c|}
\hline Formulation & Angle of repose $\mathbf{( \theta )}$ & Bulk density $(\mathbf{g} / \mathbf{m l})$ & Tapped density (g/ml) & Carr's index (\%) & Hausner's ratio \\
\hline CT1 & 40.8 & 0.466 & 0.626 & 26.55 & 1.39 \\
\hline CT2 & 35.23 & 0.581 & 0.735 & 29.95 & 1.27 \\
\hline CT3 & 39.21 & 0.588 & 0.757 & 25.32 & 1.29 \\
\hline CT4 & 22.24 & 0.595 & 0.769 & 28.62 & 1.29 \\
\hline CT5 & 25.70 & 0.602 & 0.781 & 21.91 & 1.28 \\
\hline CT6 & 21.8 & 0.617 & 0.806 & 22.44 & 1.31 \\
\hline CT7 & 23.71 & 0.641 & 0.833 & 22.04 & 1.28 \\
\hline CT8 & 38.69 & 0.649 & 0.862 & 23.70 & 1.33 \\
\hline
\end{tabular}

The prepared core tablets were evaluated and were found to exhibit satisfactory tablet characteristics as shown in Table no: 4. The drug content of all the formulations was found to exist between 90 and $100 \%$ and formulation CT3 was found to be within the USP limits as per the drug content. The in vitro disintegration time and wetting time were found to be very less for CT3 formulation that is 42 seconds and 15 seconds respectively and this batch tablets have also shown better dissolution profile (101.25\% drug release in 15 minutes) when compared to remaining formulations (Table no: 5). The results of the dissolution profiles of all the formulations were represented graphically in Fig.1.
The formulation CT3 showed optimum drug release of $101.25 \%$ within $15 \mathrm{~min}$. So, it was selected as the best core tablet formulation.

\section{Evaluation of Barrier Layer Blends and Press Coated Tablet Formulations (PCT1-PCT12)}

The barrier layer blends of all the press coated tablet formulations (PCT1-PCT12) were evaluated for flow properties and it was found that the flow property of the prepared barrier layer blend of PCT1 was fair, РCT2, РСT8 and PCT12 have passable flow properties whereas the flow ability of remaining blends was poor. The results were given in the Table no: 6 .

Table 4: Evaluation of Post Compression Parameters

\begin{tabular}{|c|c|c|c|c|c|c|c|}
\hline Formulation & $\begin{array}{c}\text { Average } \\
\text { weight (mg) }\end{array}$ & $\begin{array}{l}\text { Thickness } \\
\text { (mm) }\end{array}$ & $\begin{array}{l}\text { Hardness } \\
\left(\mathrm{kg} / \mathrm{cm}^{2}\right)\end{array}$ & $\begin{array}{l}\text { Friability } \\
\text { (\%) }\end{array}$ & $\begin{array}{c}\text { Disintegration } \\
\text { time (sec) }\end{array}$ & $\begin{array}{c}\text { Drug content } \\
(\%)\end{array}$ & $\begin{array}{l}\text { Wetting time } \\
\text { (sec) }\end{array}$ \\
\hline CT1 & 99.15 & 2.5 & 3.9 & 0.99 & 65 & 99.54 & 25 \\
\hline CT2 & 99.56 & 2.5 & 3.7 & 0.54 & 55 & 93.89 & 17 \\
\hline СТ3 & 99.16 & 2.5 & 3.4 & 0.26 & 42 & 99.67 & 15 \\
\hline CT4 & 99.8 & 2.5 & 3.5 & 0.85 & 49 & 91.78 & 16 \\
\hline CT5 & 99.1 & 2.5 & 3.8 & 0.96 & 66 & 90.65 & 26 \\
\hline CT6 & 99.5 & 2.5 & 3.9 & 0.52 & 67 & 92.85 & 25 \\
\hline CT7 & 99.8 & 2.5 & 3.6 & 0.84 & 55 & 94.79 & 17 \\
\hline СТ8 & 99.2 & 2.5 & 3.8 & 0.29 & 69 & 91.84 & 30 \\
\hline
\end{tabular}

Table 5: In vitro Dissolution Rate Studies

\begin{tabular}{|c|c|c|c|c|c|c|c|c|}
\hline \multirow{2}{*}{ Time (min) } & \multicolumn{7}{|c|}{ CUMULATIVE PERCENTAGE OF DRUG RELEASE (\%) } \\
\cline { 2 - 9 } & CT1 & CT2 & CT3 & CT4 & CT5 & CT6 & CT7 & CT8 \\
\hline $\mathbf{5}$ & 40.2 & 58.3 & 64.25 & 17.3 & 29.1 & 37.2 & 28.2 & 31.1 \\
\hline $\mathbf{1 0}$ & 47.9 & 74.2 & 85.91 & 25.3 & 35.2 & 46.5 & 55.38 & 46.01 \\
\hline $\mathbf{1 5}$ & 50.2 & 84.82 & $\mathbf{1 0 1 . 2 5}$ & 36.48 & 40.96 & 59.98 & 65.21 & 51.98 \\
\hline $\mathbf{2 0}$ & 66.31 & 88.9 & 101.1 & 49.25 & 59.8 & 64.96 & 71.91 & 64.42 \\
\hline $\mathbf{2 5}$ & 74.8 & 95.3 & - & 59.7 & 72.3 & 79.65 & 87.2 & 79.02 \\
\hline $\mathbf{3 0}$ & 86.1 & $\mathbf{1 0 3 . 1}$ & - & 70.82 & 81.8 & 85.63 & 94.2 & 84.23 \\
\hline
\end{tabular}




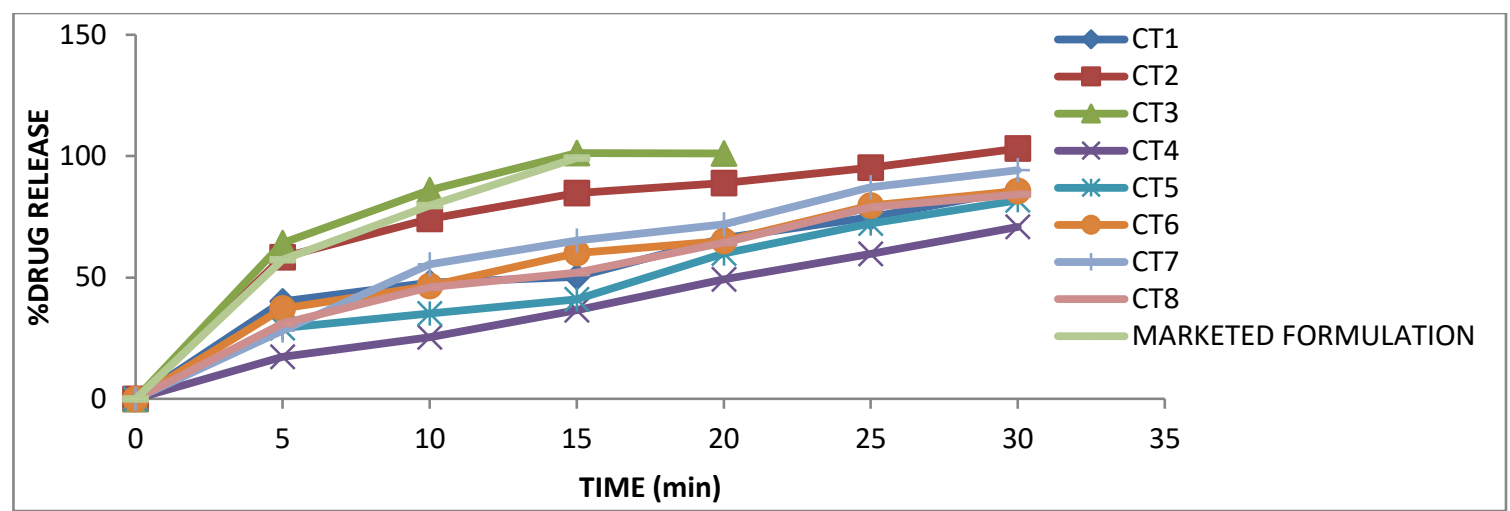

Figure 1: Dissolution Profiles of Core Tablet Formulations (CT1 - СT8)

Table 6: Evaluation of Directly Compressible Barrier Layer Blends

\begin{tabular}{|c|c|c|c|c|c|}
\hline Formulation & Angle of repose $(\boldsymbol{\theta})$ & $\begin{array}{c}\text { Bulk density } \\
(\mathbf{g} / \mathbf{m l})\end{array}$ & $\begin{array}{c}\text { Tapped density } \\
(\mathbf{g} / \mathbf{m l})\end{array}$ & Carr's index (\%) & Hausner's ratio \\
\hline PCT1 & 37.12 & 0.56 & 0.68 & 17.65 & 1.21 \\
\hline PCT2 & 41.39 & 0.48 & 0.63 & 23.81 & 1.31 \\
\hline PCT3 & 47.03 & 0.52 & 0.75 & 30.67 & 1.44 \\
\hline PCT4 & 46.45 & 0.44 & 0.61 & 27.52 & 1.39 \\
\hline PCT5 & 56.91 & 0.38 & 0.58 & 34.48 & 1.53 \\
\hline PCT6 & 46.18 & 0.41 & 0.56 & 26.79 & 1.37 \\
\hline PCT7 & 48.11 & 0.46 & 0.66 & 30.3 & 1.44 \\
\hline PCT8 & 41.96 & 0.44 & 0.57 & 22.41 & 1.29 \\
\hline PCT9 & 49.33 & 0.43 & 0.63 & 31.75 & 1.47 \\
\hline PCT10 & 57.16 & 0.36 & 0.55 & 34.55 & 1.53 \\
\hline PCT11 & 56.87 & 0.44 & 0.65 & 32.31 & 1.48 \\
\hline
\end{tabular}

The prepared press coated tablets were evaluated and were found to exhibit satisfactory tablet characteristics as discussed in Table no: 7 and 8 . The swelling index was found to be maximum at $4^{\text {th }}$ hour for the formulation PCT8.

All the press coated tablets showed distinct lag times. The formulations PCT1 to PCT4 and PCT9 to PCT12 showed very less lag times of 2-3hrs which are not consistent with the demands of chronotherapeutic drug delivery. The formulation PCT9 showed the lowest lag time of $2 \mathrm{hrs}$ with a drug release of $3.09 \%$, PCT5, РCT6 and PCT7 showed 4 hours and 3 hours lag time respectively. The formulation PCT8 with the barrier layer composition of karaya gum and locust bean gum in the ratio 1:2 showed the pre-expected lag time of 6 hours with a considerable drug release of $97.5 \%$ for 2 hours. Hence, this formulation was selected as the optimized formulation for further studies. The results of the dissolution profiles (Table no.9) of all the formulations (PCT1-PCT12) were represented graphically in Fig. 2.

Table 7: Evaluation of Press Coated Tablets

\begin{tabular}{|c|c|c|c|c|}
\hline Formulation & Average weight $\mathbf{( m g )}$ & Thickness $\mathbf{( m m})$ & Hardness $\left.\mathbf{( k g} / \mathbf{c m}^{\mathbf{2}}\right)$ & Friability $\mathbf{( \% )}$ \\
\hline PCT1 & 398.52 & 6.5 & 5.1 & 0.63 \\
\hline PCT2 & 397.6 & 6.2 & 5.2 & 0.42 \\
\hline PCT3 & 399.16 & 6.3 & 5.1 & 0.31 \\
\hline PCT4 & 399.4 & 6.3 & 5.2 & 0.55 \\
\hline PCT5 & 399.8 & 6.2 & 5.1 & 0.21 \\
\hline PCT6 & 399.1 & 6.4 & 5.2 & 0.36 \\
\hline PCT7 & 399.56 & 6.3 & 5.2 & 0.13 \\
\hline PCT8 & 399.5 & 6.5 & 5.1 & 0.11 \\
\hline PCT9 & 398.3 & 6.5 & 5.3 & 0.25 \\
\hline PCT10 & 399.57 & 6.2 & 5.2 & 0.19 \\
\hline PCT11 & 398.7 & 6.3 & 5.1 & 0.55 \\
\hline PCT12 & 399.3 & 6.5 & 5.3 & 0.32 \\
\hline
\end{tabular}


Table 8: Swelling Index (\%) of Press Coated Tablets

\begin{tabular}{|c|c|c|c|c|c|c|c|c|c|c|c|c|}
\hline Time (hrs) & РCT1 & РCT2 & РСТ3 & РСТ4 & РCT5 & РСТ6 & РСТ7 & РСТ8 & РСТ9 & РCT10 & РCT11 & РCT12 \\
\hline 0 & 0 & 0 & 0 & 0 & 0 & 0 & 0 & 0 & 0 & 0 & 0 & 0 \\
\hline 1 & 105 & 115 & 120 & 112 & 92 & 120 & 125 & 138 & 103 & 101 & 98 & 95 \\
\hline 3 & 125 & 124 & 154 & 145 & 123 & 153 & 145 & 150 & 136 & 96 & 78 & 85 \\
\hline 4 & 85 & 79 & 92 & 138 & 89 & 96 & 102 & 157 & 88 & 71 & 57 & 62 \\
\hline 6 & 50 & & 43 & 64 & 52 & 62 & 69 & 139 & & & & \\
\hline 7 & & & & & & & & 90 & & & & \\
\hline 8 & & & & & & & & 67 & & & & \\
\hline 9 & & & & & & & & 65 & & & & \\
\hline
\end{tabular}

Table 9: Percentage of Drug Release

\begin{tabular}{|c|c|c|c|c|c|c|c|c|c|c|c|c|}
\hline \multirow{2}{*}{$\begin{array}{l}\text { TIME } \\
\text { (hrs) }\end{array}$} & \multicolumn{12}{|c|}{ CUMULATIVE PERCENTAGE OF DRUG RELEASE (\%) } \\
\hline & РCT1 & РCT2 & РСТ3 & PCT4 & РCT5 & РСТ6 & РCT7 & РСТ8 & РСТ9 & РCT10 & РCT11 & РCT12 \\
\hline 0 & 0 & 0 & 0 & 0 & 0 & 0 & 0 & 0 & 0 & 0 & 0 & 0 \\
\hline 1 & 0.32 & 0.41 & 0.22 & 0.17 & 0.18 & 0.07 & 0.21 & 0.13 & 0.27 & 0.56 & 0.89 & 0.74 \\
\hline 2 & 5.75 & 5.89 & 2.87 & 2.59 & 4.69 & 2.3 & 3.1 & 0.57 & 3.09 & 5.25 & 9.99 & 7.07 \\
\hline 3 & 43.88 & 98.79 & 10.07 & 9.85 & 5.48 & 3.54 & 9.14 & 0.98 & 97.88 & 81.35 & 10.09 & 9.85 \\
\hline 4 & 94.89 & 101.71 & 76.89 & 17.85 & 8.5 & 4.59 & 21.65 & 2.09 & 100.87 & 101.32 & 66.09 & 39 \\
\hline 5 & 104.28 & & 92.44 & 78.88 & 78.64 & 25.85 & 24.88 & 5.5 & & & 87.14 & 77.98 \\
\hline 6 & & & 100.65 & 90.89 & 87.69 & 34.75 & 37.05 & 10.13 & & & 100.85 & 98.19 \\
\hline 7 & & & & 102.29 & 94.12 & 83.88 & 63.01 & 25.18 & & & & 105.09 \\
\hline 8 & & & & & 105.9 & 94.89 & 84.04 & 97.5 & & & & \\
\hline 9 & & & & & & 100 & 97.5 & 99.8 & & & & \\
\hline
\end{tabular}

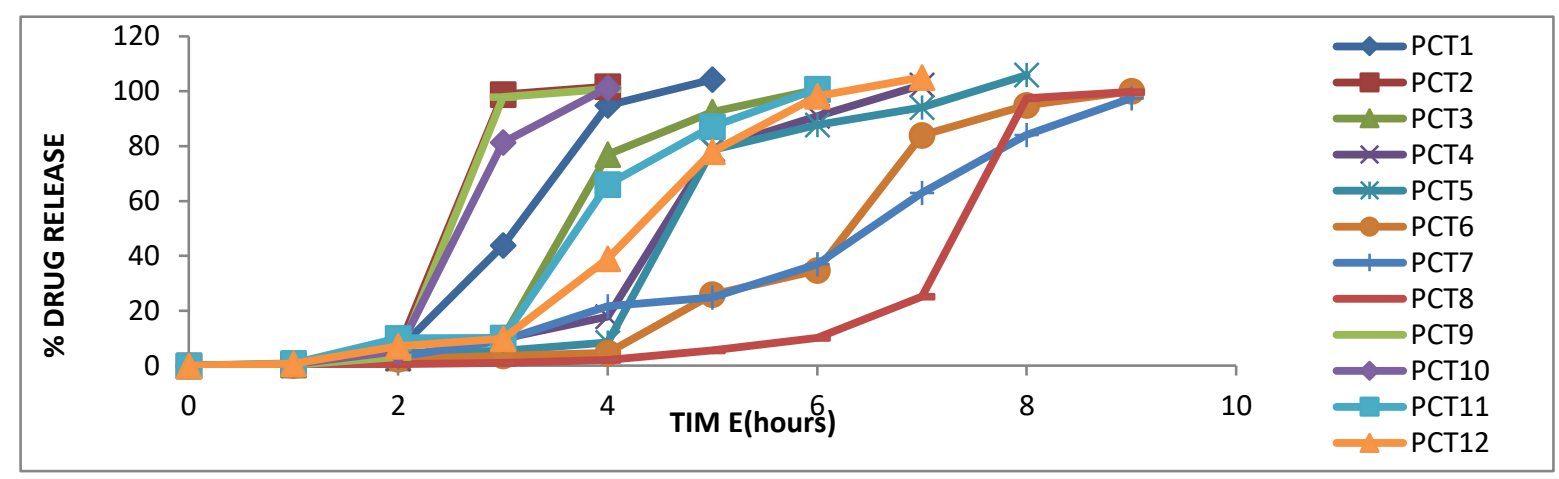

Figure 2: Dissolution Profiles of Press Coated Tablets (РCT1-РCT12)

\section{Drug-Excipient Compatibility Studies}

\section{Fourier Transform Infra-red Spectroscopy}

The FTIR spectrum of Montelukast sodium exhibited peak at $3157.4 \mathrm{~cm}^{-1}$ due to $\mathrm{N}-\mathrm{H}$ stretching and at $2923.75 \mathrm{~cm}^{-1}$ due to alkane saturated peak. The FTIR spectrums of pure drug and optimized press coated tablet formulation were shown below. There was no interference of the functional group as the principle peaks of the Montelukast sodium were found to be unaltered in the final optimized formulation, indicating they were compatible chemically. The FTIR spectrums of the pure drug and the optimized press coated tablet formulation were shown in Fig. 3 and Fig. 4 respectively.

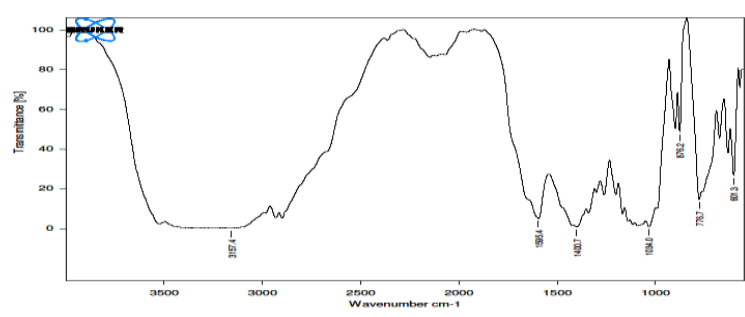

Figure 3: FTIR of Montelukast sodium (Pure Drug)

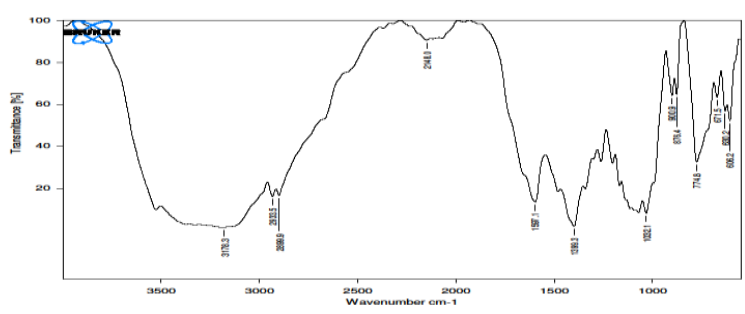

Figure 4: FTIR of Optimized Formulation (РСT8) 


\section{Differential Scanning Calorimetry}

The DSC thermograms of Montelukast sodium and optimized formulation (РCT8) exhibited endothermic peaks at $154.37^{\circ} \mathrm{C}$ and $153.78^{\circ} \mathrm{C}$ respectively which correspond to the melting point of Montelukast sodium. The DSC thermogram of the optimized formulation does not show any profound shift in the peak indicating compatibility between the drug and the excipients. The DSC thermograms of Montelukast sodium and optimized formulation (РCT8) are shown in Fig. 5 and 6 respectively.

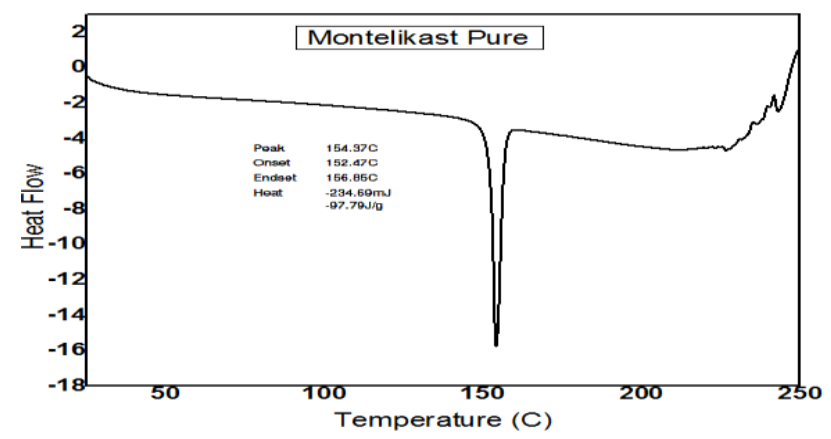

Figure 5: DSC of Montelukast sodium (Pure Drug)

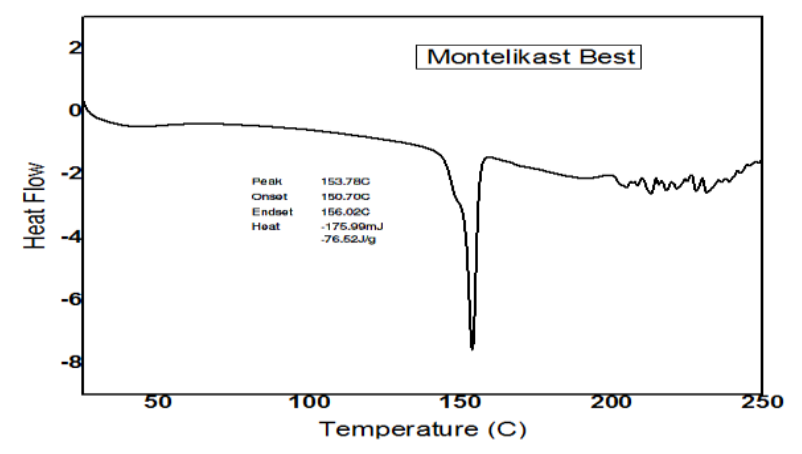

Figure 6: DSC of Optimized Formulation (PCT8)

\section{CONCLUSION}

An optimized press coated tablet formulation of Montelukast sodium (PCT8) containing Karaya gum and Locust bean gum (1:2 ratio) as the outer barrier layer was found to show single pulse drug delivery with considerable drug release for $2 \mathrm{hrs}$ after maintaining the desired lag time of 6 hours. The polymer mixture in the barrier layer provides sufficient lag time for timed release of the drug useful for chrono pharmacotherapy of asthma. The results of in vitro dissolution tests indicate that amount of polymer in the formulation affects the drug release rate. This novel press coated tablet developed for Montelukast sodium could be a promising chronotherapeutic system for the relief from increasing airway resistance during early morning hours in nocturnal asthma patients.
Acknowledgements: The authors are thankful to Institute of Pharmaceutical Technology, Sri Padmavathi Mahila Visvavidyalayam, Tirupati for providing necessary facilities to carry out the research work.

\section{REFERENCES}

1. Yie W. Chein, Novel Drug Delivery System, 2nd edition, Revised and Expanded, New York: Marcel Dekker; 2005, pp139.

2. Shayne Cox Gad, Pharmaceutical Manufacturing Handbook: Production and Processes, John Wiley and Sons, Inc Publication, pp. 348.

3. J Sajan, TA Cinu, AJ Chacko, J Litty and T Jaseeda, Chronotherapeutics and Chronotherapeutic Drug Delivery Systems, Tropical Journal of Pharmaceutical Research, $\begin{array}{lllll}\text { October 2009; } 8 & \text { (5): } & \text { pp. } 467-475 .\end{array}$ DOI: $10.4314 /$ tjpr.v8i5.48091.

4. Lemmer B, Circadian rhythms and drug delivery. J. Control.Release., 1991; 16: pp. 63-74. DOI: 10.1016/01683659(91)90031-8.

5. Sawada T, Sako K, Yoshihara K, Nakamura K, Yokohama S, Hayashi M: Timed-release formulation to avoid drug-drug interaction between diltiazem and midazolam. J.Pharm. Sci., 2003; 92: pp. 790-797. DOI: 10.1002/JPS.10336; PMID: 12661064.

6. Bailpattar Padmaxi, Karwa Preeti, Patel Kirtan, Mondal Md. Sahidullah, Pasha Mohamed Irshad, "Formulation And Evaluation of Time Controlled Drug Delivery System Of Montelukast Sodium", International Journal of Pharmaceutical Innovations, May- June 2012; Volume 2, Issue 3: pp. 1-12.

7. http://www.drugs.com/pdr/montelukastsodium.html

8. Kanaka Durga Devi. N, Narasimha Rao. N, Sai Mrudula. B, Abhinaya. M, "An Investigation and Comparison of Natural Release Polymers as Barrier Release Layers n Predictable Pulsatile Release"; Drug Discovery, Number 7, January 2013; Volume 3: pp. 7-13.

9. N. Kanaka Durga Devi, B. Sai Mrudula, A.Prameela Rani, "Chronomodulated Drug Delivery System of Montelukast sodium", Scholars Research Library, Der Pharmacia Lettre, 2010; 2(5): pp. 316-329.

10. Janugade B. U., Patil S.S., Patil S.V., Lade P.D., “ Formulation and Evaluation of Press-coated Montelukast Sodium Tablets for Pulsatile Drug Delivery System", International Journal of Chem Tech Research, July-Sept 2009; Vol.1, No.3: pp. 690695.

11. Krishnaveni.G, Muthukumaran. M, Krishnamoorthy.B, "Development and Evaluation of Pulsatile Drug Delivery System containing Montelukast Sodium by Press Coated Tablet using Natural Polysaccharides", Int J Adv Pharm Gen Res 2013; 1(2): pp. 41-51.

Source of Support: None declared.

Conflict of Interest: None declared. 